\title{
Characteristics of Fluid Inclusions and Metallogenesis of Annage Gold Deposit in Qinghai Province, China
}

\author{
Jianqing Lai ${ }^{*}$, Peijiao Ju¹, Jinjin Tao1, Baorong Yang², Xiaoyun Wang2 \\ ${ }^{1}$ Key Laboratory of Metallogenic Prediction of Nonferrous Metals, Ministry of Education, School of Geosciences \\ and Info-Physics, Central South University, Changsha, China \\ ${ }^{2}$ No. 8 Team, Qinghai Bureau of Nonferrous Metals Geological Exploration, Xining, China \\ Email: *jpeijiao@yahoo.com
}

Received 26 September 2015; accepted 21 November 2015; published 24 November 2015

Copyright (C) 2015 by authors and Scientific Research Publishing Inc.

This work is licensed under the Creative Commons Attribution International License (CC BY). http://creativecommons.org/licenses/by/4.0/

\section{(c) (7) Open Access}

\section{Abstract}

The Annage gold deposit is located at the east part of the eastern Kunlun orogenic belt. The characteristics of ore-forming fluids and metallogenesis were discussed by using fluid petrography, micro-thermometry and hydrogen-oxygen isotope analysis. Three stages, namely quartz-pyrite stage (A), quartz-polymetallic-sulfide stage (B) and quartz-ankerite stage (C) were included in the hydrothermal process as indicated by the results of this study. Inclusions developed in ore-bearing quartz veins from stages $A$ and $B$ are of three types: aqueous inclusions (type $I_{\text {), }} \mathrm{CO}_{2}$-bearing inclusions (type II) and pure $\mathrm{CO}_{2}$ inclusions (type III). All three types of inclusions, mainly type I, are presented in stage $A$, having homogenization temperatures at $180^{\circ} \mathrm{C}-360^{\circ} \mathrm{C}$, and salinities ranging from $\mathbf{0 . 5 3 \%}$ to $\mathbf{2 1 . 4 4 \%}$. In addition to development of type I inclusions, type II and III inclusions increase significantly in stage $\mathrm{B}$, with homogenization temperatures ranging from $160^{\circ} \mathrm{C}$ to $330^{\circ} \mathrm{C}$, and salinities are from $1.32 \%$ to $22.01 \%$. Based on micro-thermometry, fluids in Annage deposit are of $\mathrm{H}_{2} \mathrm{O}-\mathrm{NaCl}-\mathrm{CO}_{2}$ type with medium-high temperature $\left(140^{\circ} \mathrm{C}-395^{\circ} \mathrm{C}\right)$ and medium-low salinity (0.53\% - 22.01\%). Results of hydrogen-oxygen isotope analysis show that ore-forming fluid is mainly $\mathrm{CO}_{2}$-rich magmatic fluid, mixed with shallow groundwater or metamorphic hydrothermal in the late mineralization stages. Calculated metallogenic pressures are in the range of 79 - 130MPa corresponding to a maximum depth of $4.8 \mathrm{~km}$. The Annage deposit is a mesothermal quartz vein type gold deposit.

\section{Keywords}

Fluid Inclusions, Hydrogen-Oxygen Isotope, Ore-Forming Fluid, Metallogenesis, Annage, China

\footnotetext{
*Corresponding author.
}

How to cite this paper: Lai, J.Q., Ju, P.J., Tao, J.J., Yang, B.R. and Wang, X.Y. (2015) Characteristics of Fluid Inclusions and Metallogenesis of Annage Gold Deposit in Qinghai Province, China. Open Journal of Geology, 5, 780-794. 


\section{Introduction}

The Annage gold deposit is a typical deposit located at the central subzone of eastern Kunlun polymetallic metallogenic belt in Qinghai province, China. Intensive tectonic and magmatic activities occurred in this region, forming a series of mines with abundant resources and various genetic types. The geological characteristics, genesis and ore-forming fluids of typical deposits in this region have been the subjects of several previous studies. Based on analysis of REE, trace elements, sulfur and lead isotope, $\mathrm{Hu}$ [1] indicated that ore-forming temperature of Guoluolongwa gold deposit was from medium-high to medium-low, and mineralization fluids derive from deep magmatic hydrothermal rich in $\mathrm{SO}_{4}^{2-}$ and $\mathrm{Cl}^{-}$. Zou [2] demonstrates that Guoluolongwa gold deposit is of mesothermal type which is related to Variscan-Indosinian intermediate-acidic magmatism. Ding [3] points out ore-forming fluid in Guoluolongwa deposit is the mixture of metamorphic hydrothermal with high temperature, low salinity, high density of $\mathrm{CO}_{2}$ and magmatic hydrothermal with low temperature, medium-high salinity, and interfused with meteoric water in the late. According to geological characteristics, Qi [4] considered the Asiha gold mine as a typical fracture zone type deposit. On basis of geochemistry of wall rock and ore body, fluid inclusions as well as hydrogen and oxygen isotope, $\mathrm{Li}$ [5] reports that ore-forming fluid of Asiha deposit is mainly $\mathrm{CO}_{2}$-rich mantle-derived magmatic hydrothermal.

Few previous studies on deposit characteristics, mineral resources of Annage gold mine have been reported, and its metallogenic mechanism, especially as it pertains to the characteristics of ore fluids, remain unclear. An investigation of the metallogenic mechanism and the evolution of the ore fluids are important for ore exploration and understanding the ore-formation process. Fluid inclusions can provide abundant information on the genetic and evolutionary history of ore formation and thus play an important role in ore geology research [6]. This paper focuses on microthermometric studies and hydrogen-oxygen isotope analysis of fluid inclusions from the main mineralization episode, with an aim to characterize the thermal and compositional evolution of hydrothermal fluids and to discuss their implications for mineralization. The evolution of hydrothermal system is discussed in terms of fluid composition and temperature, with particular emphasis on the implications for fluid sources and metal deposition mechanisms [6] [7].

\section{Geologic Setting}

The study area is located at the east part of eastern Kunlun orogenic belt, and the belt is characterized by the complex processes of cracking, archipelagic ocean formation, subduction, soft collision and polycyclic orogeny in tectonic evolution [8]. Its evolution history can be divided into Precaledonian, Caledonian, Variscan-Indosinian and Yanshanian-Himalayan [9]. The outcropping rocks of the study area comprise the Palaeoproterozoic Baishahe Formation $\left(\mathrm{Pt}_{1} b\right)$, Paleozoic Ordovician-Silurian Nachitai Group (O-SN), Permian Ma'er'zheng Formation $\left(\mathrm{P}_{1} m\right)$, and Quaternary sediments $(\mathrm{Q})$ (Figure 1). Regional-scale structures in the eastern Kunlun district are dominantly EW fractures, including northern Kunlun fault, middle Kunlun fault, and southern Kunlun fault [5] [10].

The lithologies of ore field mainly include Palaeoproterozoic Baishahe Formation $\left(\mathrm{Pt}_{1} b\right)$, the lower Paleozoic Nachitai Group (O-SN) and Quaternary sediments (Q) (Figure 2). Baishahe Formation and Nachitai Group are the main ore-hosting rocks. Baishahe formation is a set of high greenschist-granulite facies metamorphic rocks dominantly composed of mica-quartz schist, marble and amphibolite; whereas Nachitai Group is a set of epimetamorphic rock series consist of chlorite phyllite, leptynite, siliceous slate, and metacryst tuff [10].

The fault structures comprise the EW large-scale shear belt and its secondary faults which can be divided into EW, NW and SN faults. The EW shear zone exposes a large scale, and spans more than $5 \mathrm{~km}$ with a width of 30 $-80 \mathrm{~m}$ and steeply southwards with an inclination of $70^{\circ}-80^{\circ}$. The most significant ore-controlling structures are the EW faults, which constrain the shape of ore bodies. The late-formed NW faults with small sizes may have damage effect on ore bodies. The NS faults suffer late dynamic modification and hydrothermal alteration, and take control of the occurrence of some gold belts.

Magmatic activity in this area exhibits multicycle and multistage features, magmatic rocks are mainly Variscan-Indosinian intermediate-acid intrusions composed of plagioclase granite, adamellite and granodiorite [12].

\section{Ore Body Characteristics}

Ore bodies with two types of mineralization are developed in the gold deposit: the quartz vein type and the al- 


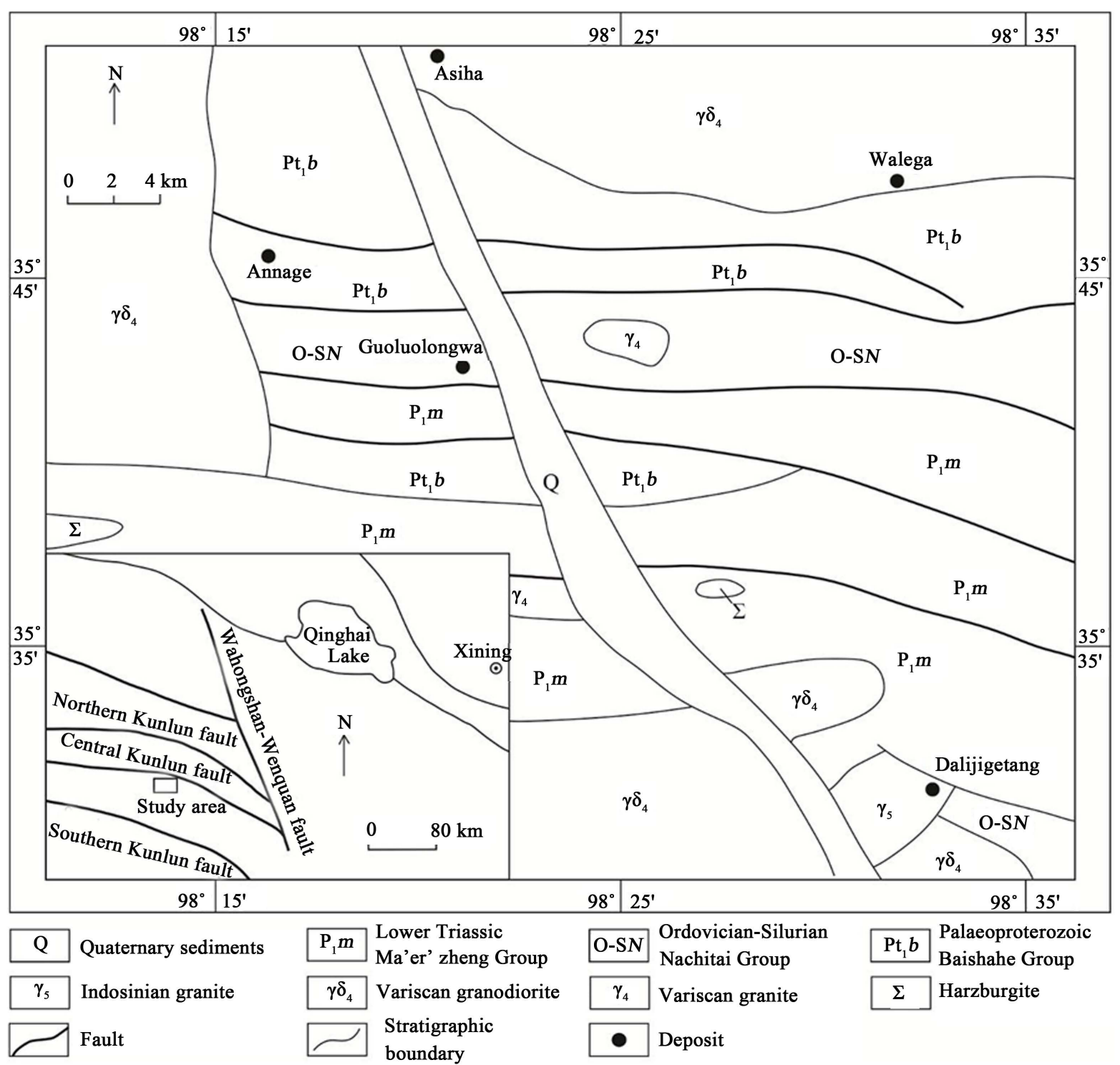

Figure 1. Regional geological map of Gouli area in Qinghai Province (modified from Zou [2]).

tered rock type, dominated by the former. Ore bodies are characterized by various sizes, and are mainly in vein and lenticular forms.

Quartz vein type ore bodies composed of multiple quartz veins are usually in parallel vein forms (Figure 3(a) and Figure 3(b)). The quartz veins are mainly in cataclastic forms with a thickness range from $1-2 \mathrm{~cm}$ to $80 \mathrm{~cm}$ for a single vein, and are interspersed by late quartz-sulfide veins, veinlets or stockworks. Few ankerites are visible on both sides of quartz veins and within the veins, forming quartz-carbonate-sulfide veins (Figure 3(c)).

Altered rock type ore bodies are generally formed nearby the quartz vein type ones, within the wall rocks between quartz veins or appear alone. Main alteration types are silicification, sericitization and pyritization (Figure 3(d)).

The main ore minerals are micro-, fine-grained native gold, pyrite, chalcopyrite, galena and sphalerite, supergene minerals include ceruloplasmin, limonite and malachite. Coarse-grained gold is formed through leaching and polymerization. The gangue minerals are mainly quartz, followed by calcite, muscovite, epidote, sericite. The textures of ores are mostly euhedral-subhedral, xenomorphic granular and interstitial textures, while ore structures are relatively simple, including massive, disseminated and stockwork structures.

Wall rock alterations are dominated by silicification, sericitization, pyritization, chloritization, epidotization, 


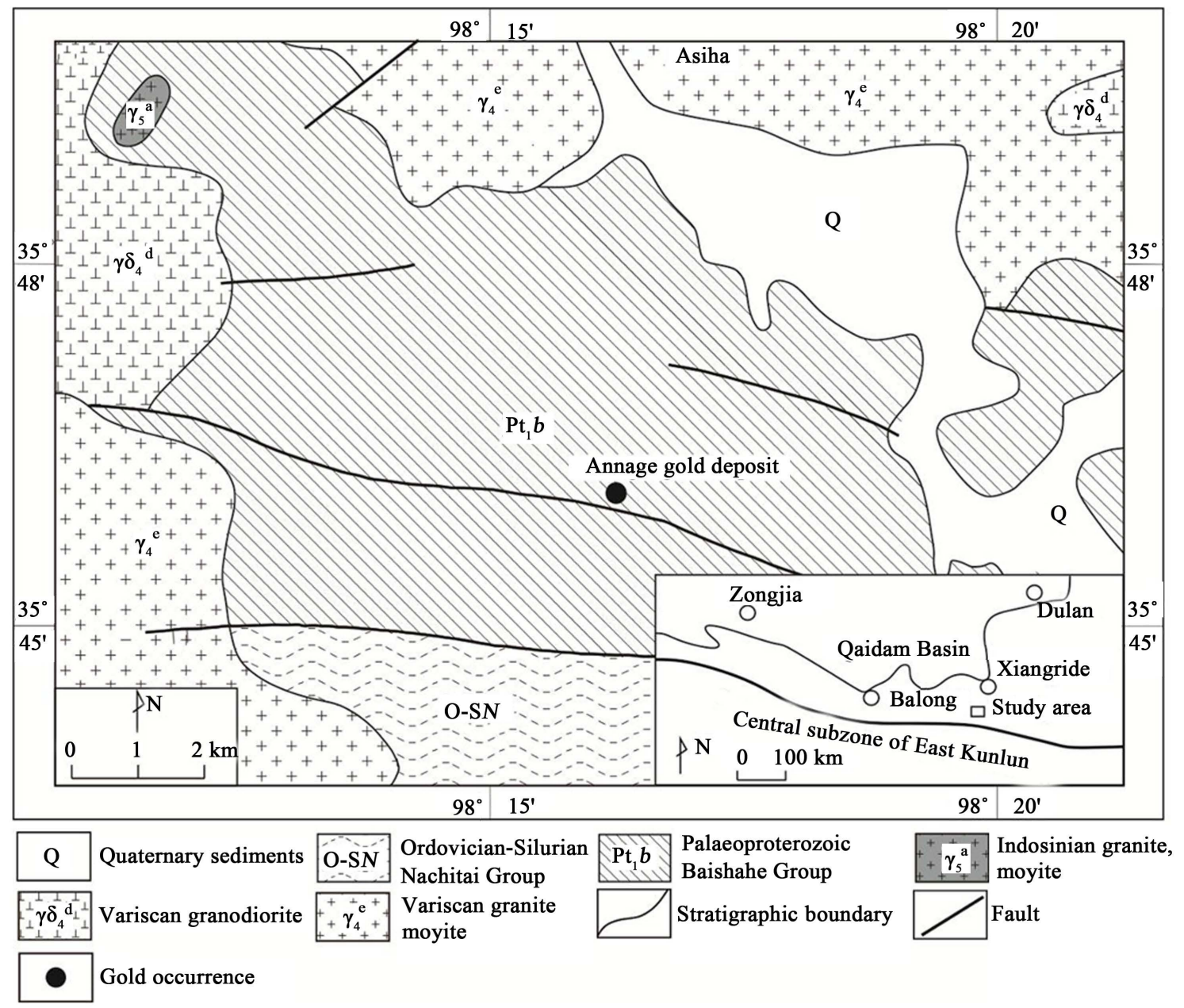

Figure 2. Geological map of the Annage gold deposit [11].

and carbonatization, among which silicification and pyritization are closely related to gold mineralization.

The Annage gold deposit experienced multiperiod mineralizations. On the basis of ore fabrics, mineralogical assemblage, and crosscutting relationships, the mineralization processes can be divided into three stages: quartz-pyrite stage (A), quartz-polymetallic-sulfide stage (B) and quartz-ankerite stage (C).

Quartz-pyrite stage (A): stage A is characterized by development of subhedral-anhedral fine-grained pyrite veinlets, and transparent quartz veinlets. In this stage, pyrite in the veins is present in coarse-grained euhedral to subhedral form, and a small amount of visible gold mineralization is observed.

Quartz-polymetallic-sulfide stage (B): stage B is the main mineralization stage and is represented by an assemblage of quartz, pyrite, chalcopyrite, galena and sphalerite. Pyrite in veins of this stage is always intergrown with other metal sulfides and is mainly in colloidal forms. Significant gold mineralization can be observed in this stage.

Quartz-ankerite stage (C): stage C is characterized by the mineralogical assemblage of calcite-ankerite-carbonate, which indicates that ore-forming fluid activities were weakening and ending. The quartz-ankerite veins sometimes contain small amount of metal sulfides. Ankerite is observed on both sides of the veinlets. Hydrothermal alterations are mainly kaolinization and carbonatization in this stage.

\section{Methods}

\subsection{Fluid Inclusion Microthermometry}

All samples used in this study were systematically collected from tunnel and trench of Annage deposit. Doubly 


\section{J. Q. Lai et al.}

polished thick sections ( 0.06 - $0.08 \mathrm{~mm}$ thick), representing different locations, ore types and stages, were prepared for fluid inclusion study. These sections were studied first for petrography to establish the relative timing of minerals, and then used for fluid inclusion micro-thermometry. Twelve of them were finally selected for heating and freezing measurements. These samples, with well-developed inclusions in quartz, provide information on the conditions of mineralization during the mineralization stages A and B. Fluid inclusions were carefully observed to identify their genetic and compositional types, vapor-liquid ratios and spatial clustering. Sample features and locations are shown in Table 1.
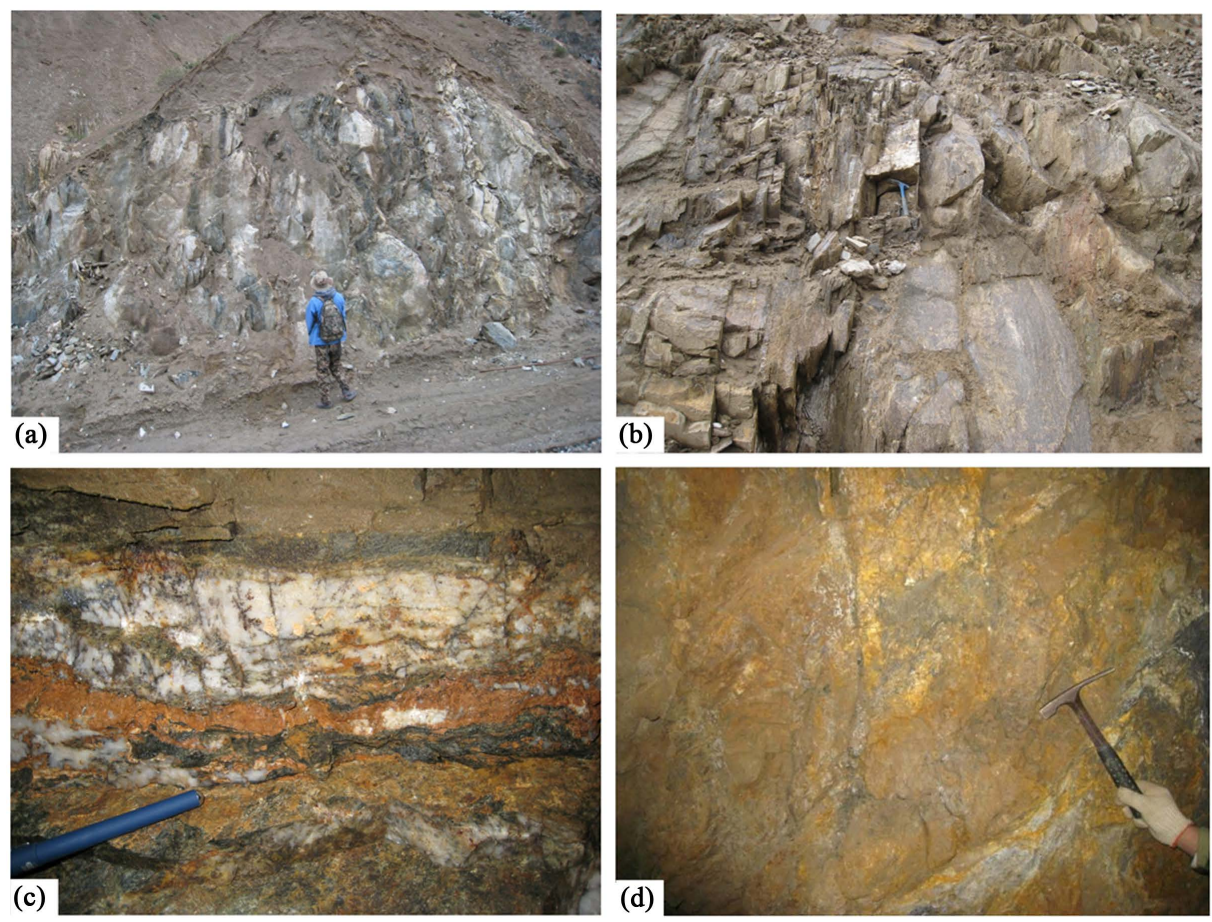

Figure 3. Ore body characteristics of Annage deposit. (a) Fracture zone of central ore vein; (b) Quartz vein type ore body; (c) Ore bodies with parallel composite morphology; (d) Altered rock type ore body.

Table 1. Characteristics and locations of samples studied for microthermometry.

\begin{tabular}{|c|c|c|c|c|}
\hline No. & Sample No. & Location & Description & Stage \\
\hline 1 & B-12 & Mining tunnel of AuI belt & Ore-bearing quartz vein & B \\
\hline 2 & B-13 & Mining tunnel of AuI belt & Ore-bearing quartz vein & A \\
\hline 3 & B-14 & Mining tunnel of AuII belt & Ore-bearing quartz vein & A \\
\hline 4 & B-15 & Mining tunnel of AuII belt & Ore-bearing quartz vein & A \\
\hline 5 & An-6 & Trench of AuI belt & Pyrite-bearing quartz vein & B \\
\hline 6 & An-8 & Trench of AuII belt & Pyrite-bearing quartz vein & B \\
\hline 7 & An-12 & Trench of AuII belt & Milonitic ore-bearing quartz vein & A \\
\hline 8 & An-14 & Trench of AuII belt & Ore-bearing quartz vein & $\mathrm{B}$ \\
\hline 9 & Gak-2 & 3710 middle of AuII belt & Quartz vein containing pyrite, galena & $\mathrm{B}$ \\
\hline 10 & Gak-3 & 3711 middle of AuII belt & Quartz vein containing pyrite, galena & $\mathrm{B}$ \\
\hline 11 & Gak-4 & 3712 middle of AuII belt & Quartz vein containing pyrite, galena & B \\
\hline 12 & Gap1-12 & Outcrop of AuI belt & Ore-bearing quartz vein & A \\
\hline
\end{tabular}


Micro-thermometric measurements were performed using the Linkam THMS 600 heating-freezing stage in the laboratory of fluid inclusions of Central South University. The stage, which was calibrated by using synthetic fluid inclusions, has a maximum temperature limit of $600^{\circ} \mathrm{C}$ and a minimum temperature limit of $-196^{\circ} \mathrm{C}$. The estimated precisions of the measurements are $\pm 0.1^{\circ} \mathrm{C}$ and $\pm 1^{\circ} \mathrm{C}$ for freezing and heating, respectively. The heating/freezing rate generally ranged from $0.2^{\circ} \mathrm{C} / \mathrm{min}$ to $5^{\circ} \mathrm{C} / \mathrm{min}$ but decreased to $<0.2^{\circ} \mathrm{C} /$ min near phase transformation.

The measurements include freezing temperatures (Tf), incipient melting temperatures of ice (Ti-ice), ice melting temperatures (Tm-ice), $\mathrm{CO}_{2}$ melting temperatures $\left(\mathrm{Tm}-\mathrm{CO}_{2}\right)$, clathrate melting temperatures (Tm-cla), homogenization temperatures of $\mathrm{CO}_{2}\left(\mathrm{Th}-\mathrm{CO}_{2}\right)$, and total homogenization temperatures (Th). Salinities of $\mathrm{NaCl}-\mathrm{H}_{2} \mathrm{O}$, and $\mathrm{CO}_{2}$-bearing FIs were estimated by the final ice melting temperatures and clathrate melting temperatures of $\mathrm{CO}_{2}$ clathrate, respectively, by using the equation of Brown and Lamb [13] in the computer program of FLINCOR [14].

\subsection{Hydrogen-Oxygen Isotope Analysis}

Four samples (An-2, An-6, An-8, An-14) from quartz-polymetallic-sulfide veins in stage B were used to identify the oxygen and hydrogen isotope compositions of quartz. Hydrogen and oxygen isotope analyses were measured on a MAT-253 mass spectrometer at IGGCAS. Quartz samples were hand-picked and/or separated by using a magnetic separator. Oxygen was liberated from quartz by reaction with $\mathrm{BrF}_{5}$ [15] and converted to $\mathrm{CO}_{2}$ on a platinum-coated carbon rod. The hydrogen isotopic compositions of the fluid inclusions were analyzed on the samples. Samples were first degassed of labile volatiles by being heated under a vacuum at $150^{\circ} \mathrm{C}$ for $3 \mathrm{~h}$. Water was converted to hydrogen by passage over heated zinc powder at $410^{\circ} \mathrm{C}$ [16]. Stable isotope data for hydrogen and oxygen are expressed in the standard $\delta$ notation as per million (\%) relative to standard mean ocean water (SMOW). The precision of measurements for stable isotopes was $\pm 0.2 \%$ for $\delta^{18} \mathrm{O}$ and $\pm 2 \%$ for $\delta \mathrm{D}$.

\section{Results}

\subsection{Fluid Inclusion Microthermometry}

\subsubsection{Fluid Inclusion Petrography}

Well-developed primary inclusions are observed in mineralization quartz veins from stages A and B. According to the nature of phase relationships at room temperature and phase transitions during heating and cooling, three types of fluid inclusions can be recognized (Figure 4), namely aqueous inclusion (type I), $\mathrm{CO}_{2}$-bearing inclusion (type II) and pure $\mathrm{CO}_{2}$ inclusion (type III). We describe these as follows:

Type I: aqueous inclusions. Type I fluid inclusions are aqueous inclusions with a bubble at room temperature $\left(20^{\circ} \mathrm{C}\right)$ (Figure 4(a)), homogenize to liquid phase and account for $65 \%$ of all inclusions. They are randomly distributed in quartz and coexisting with type II and type III inclusions, 2 - $21 \mu \mathrm{m}$ in diameter, and elliptical, irregular or long strip in shape. They also have variable vapor/liquid ratios ranging from $8 \%$ to $60 \%$, mainly in a range of $15 \%-30 \%$.

Type II: $\mathrm{CO}_{2}$-bearing inclusions. These are present as three-phase (vapor $\mathrm{CO}_{2}+$ liquid $\mathrm{CO}_{2}+$ liquid $\mathrm{H}_{2} \mathrm{O}$; Figure $4(\mathrm{~b})$ ) inclusions, and account for $20 \%$ of all inclusions. These inclusions are distributed in quartz isolated or in groups, 3 - $12 \mu \mathrm{m}$ in diameter, irregular or elliptical in shape and can be divided into two subtypes based on the phase assemblages and homogenization behavior. Subtype IIa inclusions contain two carbon dioxide phases (liquid and vapor, which homogenize to liquid or vapor) and an aqueous phase at room temperature (C/T $<50 \%$ ), homogenize by disappearance of the $\mathrm{CO}_{2}$ phase, whereas subtype IIb fluid inclusions are characterized by a large carbon dioxide bubble (one or two) and a minor aqueous phase (C/T $>50 \%$ ), with total homogenization by expansion of the $\mathrm{CO}_{2}$ phase.

Type III: pure $\mathrm{CO}_{2}$ inclusions. Type III inclusions are present as two $\mathrm{CO}_{2}$ phases (liquid and vapor) at room temperature (Figure 4(c)), and account for $15 \%$ of all inclusions. These inclusions are commonly distributed in groups, and coexist with the other inclusion types (Figure 4(d)). They are variable in shape, including irregular and elliptical, with sizes mainly of 3 - $8 \mu \mathrm{m}$.

\subsubsection{Microthermometric Results}

Twelve of these samples were selected for heating and freezing measurements, and 223 fluid inclusions were 

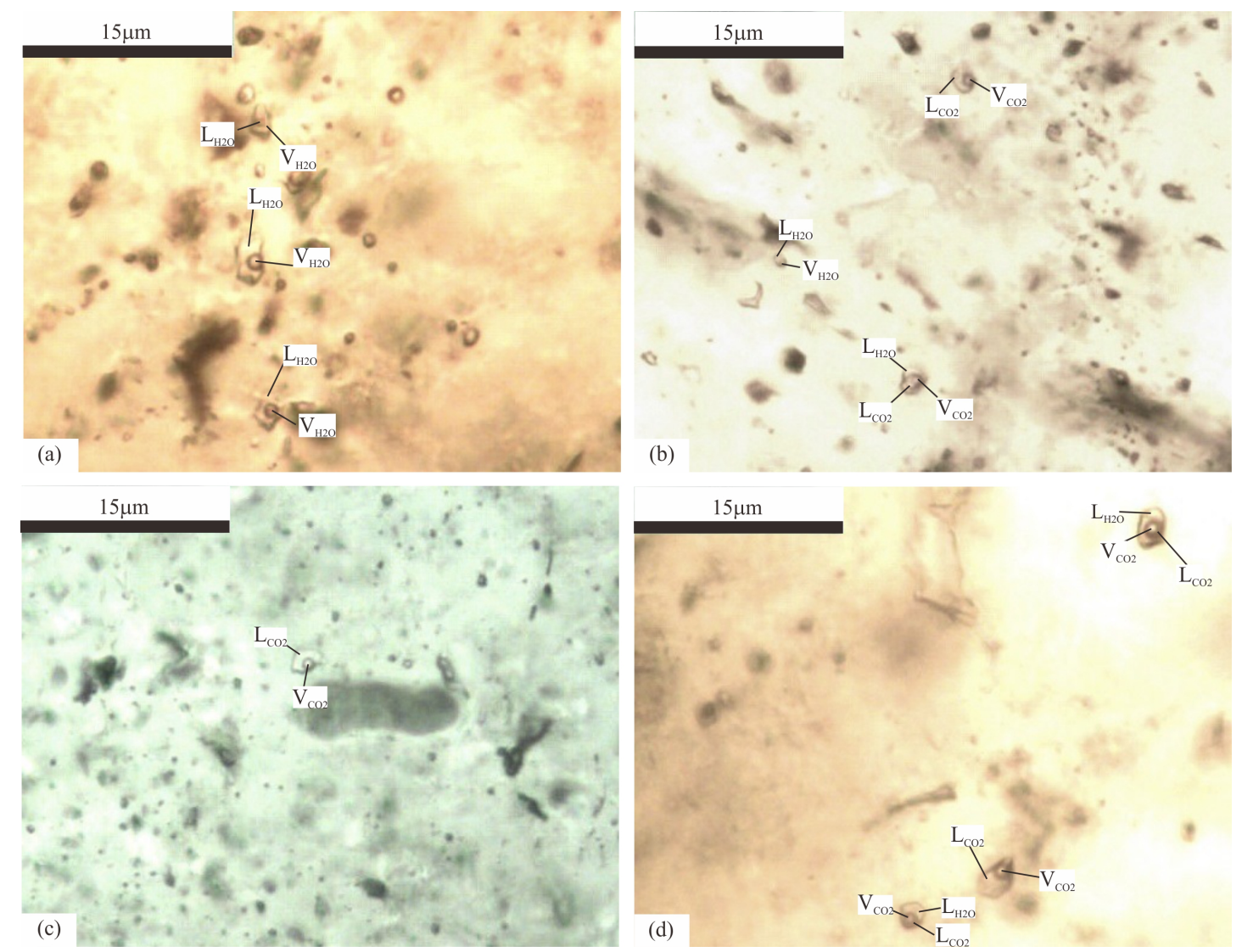

Figure 4. Microphotographs of fluid inclusions in the Annage gold deposit. (a) Aqueous inclusions (type I); (b) Type I inclusions coexist with type II, type III inclusions; (c) Pure $\mathrm{CO}_{2}$ inclusions (type III); (d) Type II inclusions coexist with type III inclusions. Abbr: $\mathrm{LH}_{2} \mathrm{O}$-liquid $\mathrm{H} 2 \mathrm{O}$; VH2O-vapor $\mathrm{H} 2 \mathrm{O}$; $\mathrm{LCO}_{2}$-liquid $\mathrm{CO}_{2}$; $\mathrm{VCO}_{2}$-vapor $\mathrm{CO}_{2}$.

measured. The microthermometric results for mineralization stages A and B are summarized in Table 2 and illustrated in histograms of homogenization temperature and salinity (Figure 5).

(1) Stage A

All three types of inclusions are present in quartz of stage A and a total of 83 are measured, among which 64 are type I inclusions, 12 are type IIa inclusions and 7 are type III inclusions.

Type I: The freezing temperatures of type I inclusions range from $-69.6^{\circ} \mathrm{C}$ to $-37.9^{\circ} \mathrm{C}$, and first melting temperatures range from $-34.7^{\circ} \mathrm{C}$ to $-21.4^{\circ} \mathrm{C}$. The final ice melting temperatures range from $-17.8^{\circ} \mathrm{C}$ to $-0.3^{\circ} \mathrm{C}$, with calculated salinities from $0.53 \%$ to $10.82 \%$ (wt\% NaCl equiv.) (Figure 5(b)). The inclusions are totally homogenized to liquid at $180^{\circ} \mathrm{C}-352^{\circ} \mathrm{C}$, clustering around $180^{\circ} \mathrm{C}-300^{\circ} \mathrm{C}$ (Figure 5(a)).

Type II: Type IIa inclusions are found in stage A. The freezing temperature of $\mathrm{CO}_{2}$ ranges from $-99.8^{\circ} \mathrm{C}$ to $-88.7^{\circ} \mathrm{C}$. All type IIa fluid inclusions are homogenized by disappearance of the $\mathrm{CO}_{2}$ phase at temperatures ranging from $268^{\circ} \mathrm{C}$ to $366^{\circ} \mathrm{C}$ (Figure 5(a)), with the most carbonic phases being homogenized to liquid at temperatures from $-3.2^{\circ} \mathrm{C}$ to $30.5^{\circ} \mathrm{C}$ and two to vapor at $29.6^{\circ} \mathrm{C}$ and $29.9^{\circ} \mathrm{C}$, respectively. The melting temperatures of the solid range from $-57.0^{\circ} \mathrm{C}$ to $-59.2^{\circ} \mathrm{C}$, below the triple-phase point $\left(-56.5^{\circ} \mathrm{C}\right)$ of $\mathrm{CO}_{2}$, suggesting minor amounts of dissolved components in the carbonic phase [17]. Clathrate melting occurs in the interval from $-10.0^{\circ} \mathrm{C}$ to $8.8^{\circ} \mathrm{C}$, with corresponding salinities between $2.39 \%$ and $21.44 \%$ (Figure $5(\mathrm{~b})$ ).

Type III: The freezing temperatures of $\mathrm{CO}_{2}$ range from $-99.5^{\circ} \mathrm{C}$ to $-85.2^{\circ} \mathrm{C}$, and melting temperatures of solid from $-58.1^{\circ} \mathrm{C}$ to $-57.6^{\circ} \mathrm{C}$. Fluid inclusions are totally homogenized to liquid at temperatures ranging from $4.5^{\circ} \mathrm{C}$ to $25.1^{\circ} \mathrm{C}$.

(2) Stage B

All three types of inclusions are well-developed in quartz of stage B and a total of 140 are measured. Type II and III inclusions are much more than those of stage A. 


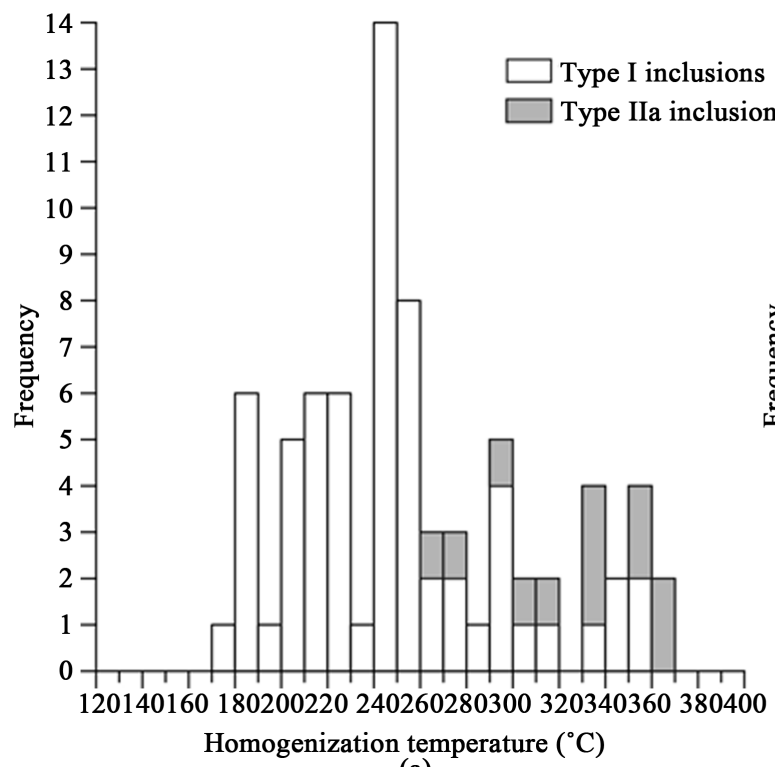

(a)

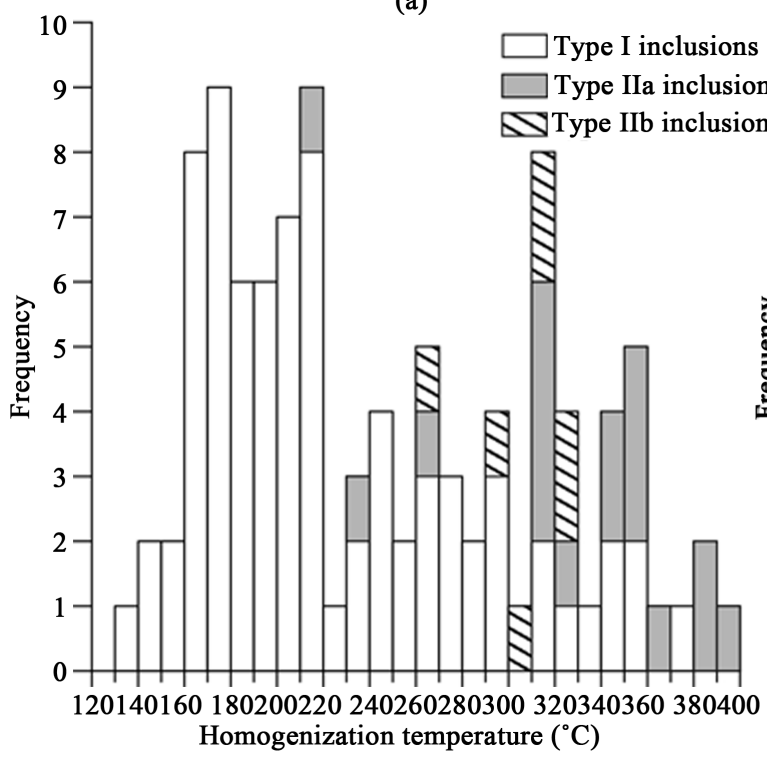

(c)

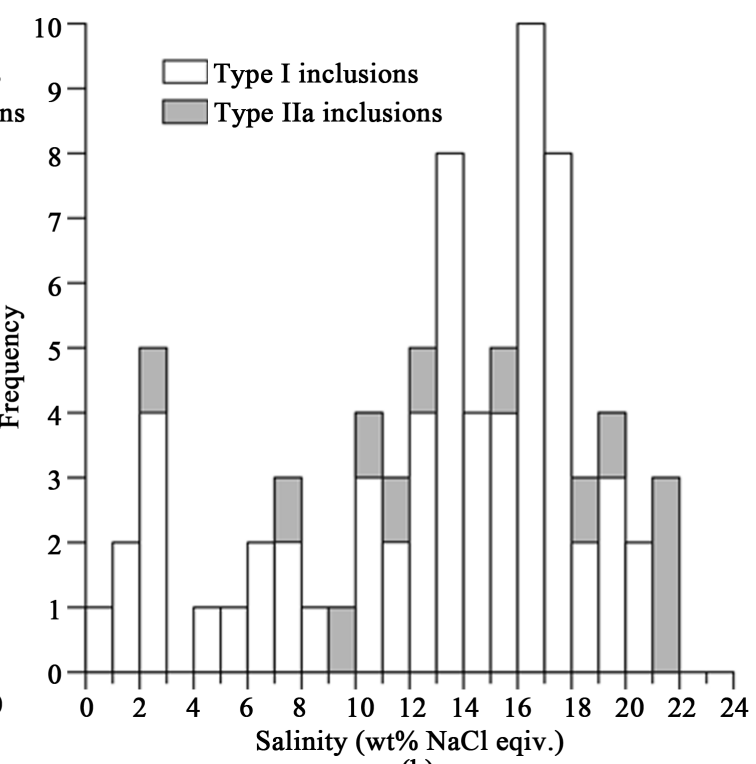

(b)

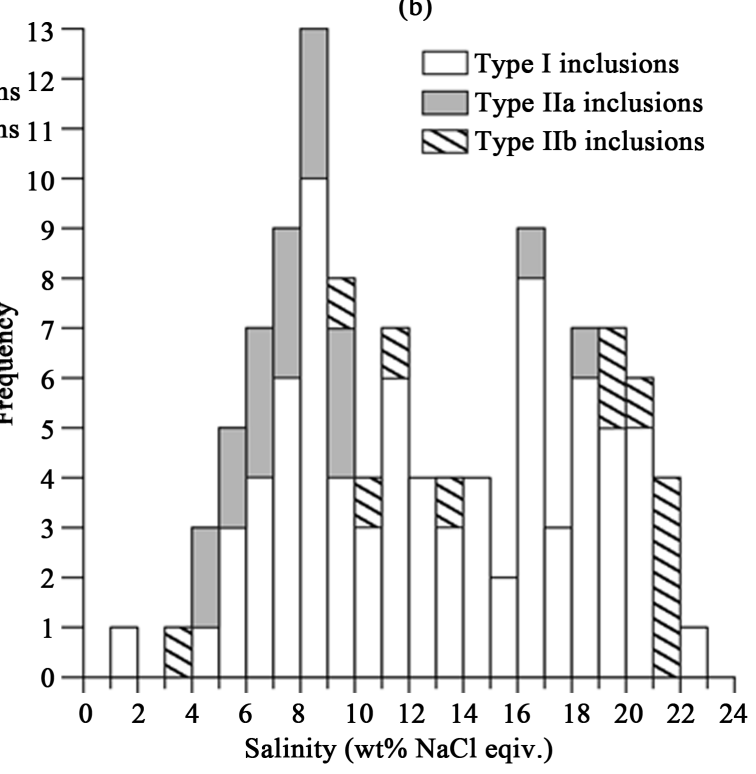

(d)

Figure 5. Histograms of homogenization temperature and salinities of fluid inclusions in different stages. (a) Quartz-pyrite stage homogenization temperatures; (b) Quartz-pyrite stage salinities; (c) Quartz-polymetallic sulfide stage homogenization temperatures; (d) Quartz-polymetallic sulfide stage salinities.

Type I: The freezing temperatures of type I inclusions range from $-63.5^{\circ} \mathrm{C}$ to $-37.7^{\circ} \mathrm{C}$, and first melting temperatures range from $-33.8^{\circ} \mathrm{C}$ to $-21.3^{\circ} \mathrm{C}$. Their final ice melting temperatures range from $-19.5^{\circ} \mathrm{C}$ to $-0.8^{\circ} \mathrm{C}$, yielding salinities of $1.32 \%-22.01 \%$ (Figure $5(\mathrm{~d})$ ). The inclusions are totally homogenized to liquid at $140^{\circ} \mathrm{C}-$ $380^{\circ} \mathrm{C}$, concentrating in the range of $160-250^{\circ} \mathrm{C}$ (Figure $5(\mathrm{c})$ ).

Type II: Type IIa and IIb inclusions are observed in stage B. The freezing temperatures of $\mathrm{CO}_{2}$ range from $-106.3^{\circ} \mathrm{C}$ to $-87.5^{\circ} \mathrm{C}$. All FIs are homogenized at temperatures ranging from $196^{\circ} \mathrm{C}$ to $395^{\circ} \mathrm{C}$ (Figure 5 (c)), with the most carbonic phases being homogenized to liquid at temperatures from $-3.2^{\circ} \mathrm{C}$ to $29.5^{\circ} \mathrm{C}$ and one to vapor at $29.5^{\circ} \mathrm{C}$. Melting temperatures of $\mathrm{CO}_{2}$ range from $-59.6^{\circ} \mathrm{C}$ to $-55.6^{\circ} \mathrm{C}$. Clathrate melting temperatures range from $-9.8^{\circ} \mathrm{C}$ to $8.3^{\circ} \mathrm{C}$, corresponding to calculated salinities from $3.33 \%$ to $21.41 \%$ (Figure 5 (d)).

Type III: The freezing temperatures of $\mathrm{CO}_{2}$ range from $-102.4^{\circ} \mathrm{C}$ to $-81.5^{\circ} \mathrm{C}$, and melting temperatures of $\mathrm{CO}_{2}$ range from $-59.6^{\circ} \mathrm{C}$ to $-55.6^{\circ} \mathrm{C}$. Fluid inclusions are homogenized to liquid from $-7.9^{\circ} \mathrm{C}$ to $25.5^{\circ} \mathrm{C}$. 
Table 2. Microthermometric data of fluid inclusions in the Annage gold deposit.

\begin{tabular}{|c|c|c|c|c|c|c|c|c|c|c|c|c|}
\hline $\begin{array}{c}\text { Sample } \\
\text { No. }\end{array}$ & Stage & Type & Counts & Size $/ \mu \mathrm{m}$ & $\begin{array}{c}\mathrm{V} / \mathrm{T}(\mathrm{C} / \mathrm{T}) / \% \\
\left(20^{\circ} \mathrm{C}\right)\end{array}$ & $\mathrm{T}_{\mathrm{m}(\mathrm{CO} 2)} /{ }^{\circ} \mathrm{C}$ & $\mathrm{T}_{\mathrm{m} \text { (ice) }} /{ }^{\circ} \mathrm{C}$ & $\mathrm{T}_{\mathrm{m}(\mathrm{cla})} /{ }^{\circ} \mathrm{C}$ & $\mathrm{T}_{\mathrm{h}(\mathrm{CO} 2)} /{ }^{\circ} \mathrm{C}$ & $\mathrm{T}_{\mathrm{h}} /{ }^{\circ} \mathrm{C}$ & Salinity/(\%) & $\begin{array}{l}\text { Density/ } \\
\left(\mathrm{g} / \mathrm{cm}^{3}\right)\end{array}$ \\
\hline B-12 & B & I & 20 & $2-6$ & $10-30$ & & $-7.8--3.7$ & & & $167-274$ & $6.01-11.46$ & $0.85-0.99$ \\
\hline \multirow{2}{*}{ B-13 } & \multirow{2}{*}{ A } & I & 19 & $2-10$ & $15-30$ & & $-17.8--2.6$ & & & $182-343$ & $4.34-20.82$ & $0.82-1.04$ \\
\hline & & IIa & 1 & 5 & 40 & -58.6 & & -9.7 & $29.6(\mathrm{~V})$ & 355 & 21.44 & 0.33 \\
\hline \multirow{3}{*}{ B-14 } & \multirow{3}{*}{ A } & I & 25 & $2-8$ & $15-30$ & & $-17.6--0.8$ & & & $180-267$ & $1.40-20.67$ & $0.80-1.01$ \\
\hline & & IIa & 2 & $4-6$ & $40-50$ & $-58.5--58.1$ & & $-9.3--10.0$ & $12.1-24.8$ & $356-366$ & $21.34-21.44$ & $0.72-0.85$ \\
\hline & & III & 3 & $4-8$ & $15-35$ & $-57.8--57.6$ & & & $4.5-24.1$ & & & $0.73-0.90$ \\
\hline \multirow{3}{*}{ B-15 } & \multirow{3}{*}{ A } & I & 15 & $2-8$ & $15-60$ & & $-15.6--0.3$ & & & $184-351$ & $0.53-19.13$ & $0.57-0.99$ \\
\hline & & IIa & 7 & $4-6$ & $45-75$ & $-59.2--57.9$ & & $-5.0-8.8$ & $29.9(\mathrm{~V})-30.5$ & $298-364$ & $2.39-19.68$ & $0.34-0.60$ \\
\hline & & III & 4 & $4-7$ & $15-35$ & $-58.1--57.8$ & & & $24.2-25.1$ & & & $0.71-0.72$ \\
\hline \multirow{2}{*}{ An-6 } & \multirow{2}{*}{ B } & I & 16 & $5-17$ & $8-20$ & & $-17.2--4.9$ & & & $153-273$ & $7.68-20.35$ & $0.85-1.06$ \\
\hline & & IIa & 5 & $5-8$ & $15-20$ & $-57.6--56.9$ & & $5.2-7.0$ & $10.4-28.5$ & $220-321$ & $5.68-8.66$ & $0.64-0.86$ \\
\hline \multirow{2}{*}{ An-8 } & \multirow{2}{*}{ B } & I & 32 & $4-21$ & $10-60$ & & $-19.5--8.2$ & & & $140-380$ & $11.94-22.01$ & $0.77-1.07$ \\
\hline & & IIa & 2 & $8-10$ & 30 & -56.9 & & $-0.5-2.5$ & $24.1-25.2$ & 353 & $12.55-16.05$ & $0.71-0.72$ \\
\hline An-12 & A & IIa & 2 & $9-11$ & $18-30$ & $-58.0--57.0$ & & $3.0-5.8$ & $27.2-29.5$ & $268-280$ & $7.70-11.88$ & $0.62-0.67$ \\
\hline An-14 & B & IIa & 11 & $7-12$ & $20-60$ & $-58.1--57.0$ & & $4.5-7.8$ & $14.5-29.5$ & $320-395$ & $4.26-9.74$ & $0.62-0.83$ \\
\hline \multirow{3}{*}{ Ak-2 } & \multirow{3}{*}{ B } & I & 6 & $3-6$ & $20-45$ & & $-13.6--0.8$ & & & $172-346$ & $1.32-17.42$ & $0.67-0.95$ \\
\hline & & $\mathrm{IIb}$ & 3 & $3-5$ & $50-75$ & $-58.5--56.9$ & & $-4.0--0.7$ & $22.8-29.5(\mathrm{~V})$ & $263-346(C)$ & 16.26 - 19.00 & $0.33-0.74$ \\
\hline & & III & 3 & $3-8$ & $20-35$ & $-55.6--58.3$ & & & $15.5-25.4$ & & & $0.71-0.82$ \\
\hline \multirow{3}{*}{ Ak-3 } & \multirow{3}{*}{ B } & I & 2 & 3 & $25-55$ & & $-5.4--5.3$ & & & $196-222$ & $8.24-8.38$ & $0.91-0.93$ \\
\hline & & IIb & 4 & $3-5$ & $50-70$ & $-59.5--58.2$ & & $-9.8--8.3$ & $-3.2-13.5$ & & $3.33-21.41$ & $0.83-0.95$ \\
\hline & & III & 14 & $3-5$ & $15-45$ & $-59.6--58.1$ & & & $-7.9-25.1$ & & & $0.31-0.97$ \\
\hline \multirow{2}{*}{ Ak-4 } & \multirow{2}{*}{ B } & IIb & 8 & $4-6$ & $45-85$ & $-59.5--58.3$ & & $-9.8-4.4$ & $6.3-29.5$ & $270-330(C)$ & ) $9.89-21.41$ & $0.62-0.89$ \\
\hline & & III & 12 & $3-5$ & $20-55$ & $-59.3--58.3$ & & & $9.5-25.5$ & & & $0.70-0.87$ \\
\hline Apl-12 & A & I & 4 & 45 & & -13.6 & & & & 352 & 17.42 & 0.85 \\
\hline
\end{tabular}

Notes: All host minerals are quartz; V/T(C/T)-vapor $\left(\mathrm{CO}_{2}\right)$ /total ratio; $\mathrm{Tm}\left(\mathrm{CO}_{2}\right)$-melting temperature of $\mathrm{CO}_{2}$; Tm(ice)-melting temperature of ice; $\mathrm{Tm}$ (cla)-melting temperature of clathrate $\mathrm{CO}_{2}$; Th( $\left(\mathrm{CO}_{2}\right)$-homogenization temperature of $\mathrm{CO}_{2}$, V-homogenize to $\mathrm{CO}_{2}$ vapor phase, others all homogenize to $\mathrm{CO}_{2}$ liquid phase; Th-homogenization temperature, C-homogenize to carbon phase, others all homogenize to aqueous phase.

\subsection{Hydrogen-0xygen Isotope Characteristics}

The hydrogen-oxygen isotope analysis results of four quartz samples from stage B are present in Table 3 . The $\delta^{18} \mathrm{O}$ values of quartz and $\delta \mathrm{D}$ values of fluids are from $10.6 \times 10^{-3}$ to $12.9 \times 10^{-3}$ and from $-83.8 \times 10^{-3}$ to -72.3 $\times 10^{-3}$, respectively (Figure 6).

Using the equation $1000 \ln \alpha=3.38 \times\left(10^{6} / \mathrm{T}^{2}\right)-3.40$ of Clayton [19] and the corresponding fluid inclusions homogenization temperatures $\mathrm{T}$ of the samples, we can calculate oxygen isotopic compositions of the oreforming fluids from quartz and the $\delta \mathrm{D}_{\mathrm{V}-\mathrm{smow}}$ values of the extracted waters for quartz samples. Overall average homogenization temperature of FIs in Annage deposit was measured as $330^{\circ} \mathrm{C}$, taking $\mathrm{T}=603 \mathrm{~K}$. The calculated $\delta^{18} \mathrm{OH}_{2} \mathrm{O}$ values of fluids are from $4.2 \times 10^{-3}$ to $6.5 \times 10^{-3}$. 


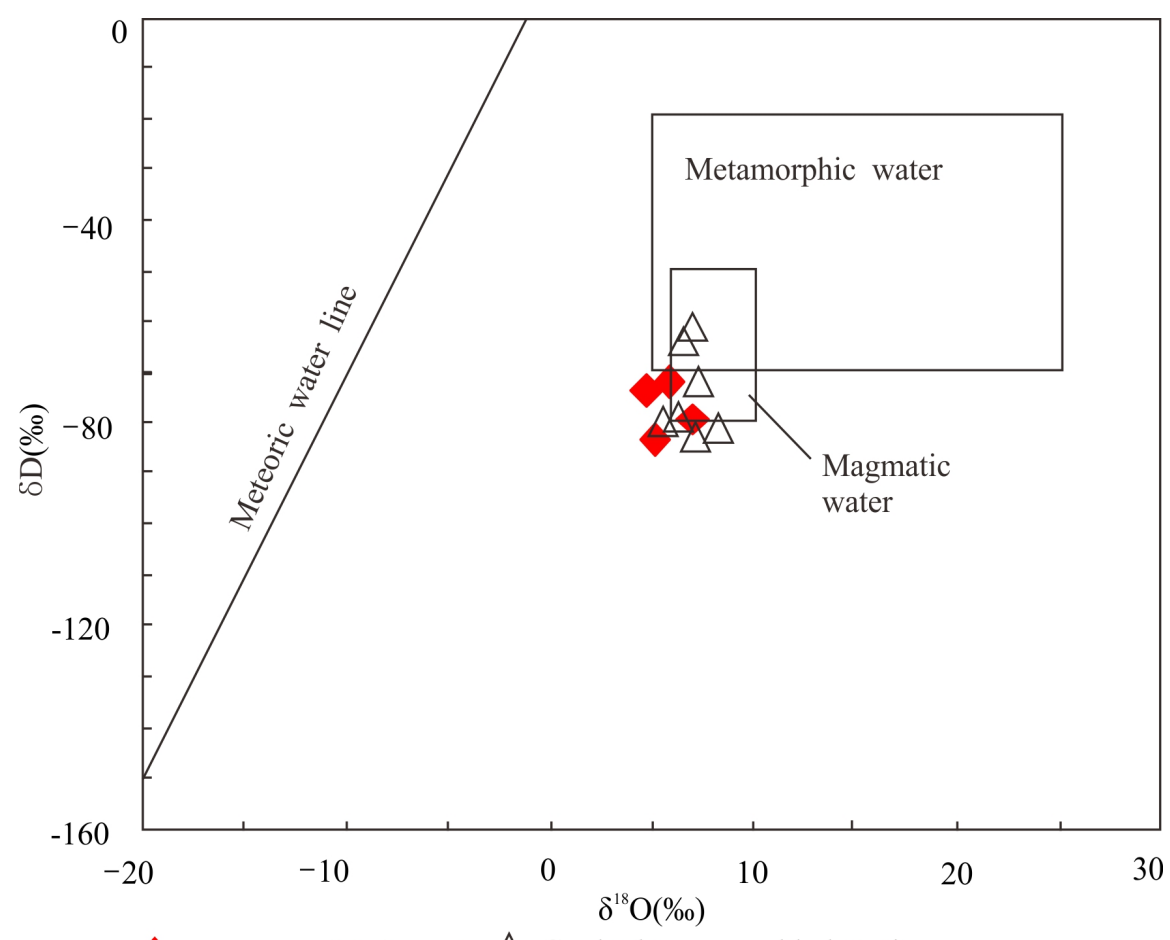

Annage gold deposit $\triangle$ Guoluolongwa gold deposit

Figure 6. $\delta \mathrm{D}-\delta 18 \mathrm{OH}_{2} \mathrm{O}$ diagram of the ore-forming fluids in Annage deposit (According to Sheppard [18]) (Data of Guoulolongwa gold deposit is from Ding [3]).

Table 3. Hydrogen-oxygen isotope compositions of Annage gold deposit.

\begin{tabular}{ccccccc}
\hline Sample No. & Mineral & Location & Description & $\delta^{18} \mathrm{O}_{\text {V-SMош }}(\%)$ & $\delta^{18} \mathrm{O}_{\text {н2о }}(\%)$ & $\delta^{18} \mathrm{D}_{\text {H2о }}(\%$ ) \\
\hline An-2 & Quartz & AuIII belt & Ore-bearing quartz vein & 12.9 & 7.0 & -79.2 \\
An-6 & Quartz & AuI belt & Ore-bearing quartz vein & 11.0 & 5.1 & -83.3 \\
An-8 & Quartz & AuIl belt & Ore-bearing quartz vein & 10.6 & 4.7 & -74.0 \\
An-14 & Quartz & AuII belt & Ore-bearing quartz vein & 11.7 & 5.8 & -72.3 \\
\hline
\end{tabular}

\section{Discussion}

\subsection{Characteristics of Ore-Forming Fluid}

According to microthermometric data, different types of inclusions with variable vapor/total ratios coexist in the mineralized quartz veins of Annage deposit, reflecting the heterogeneous state of fluid during inclusions capture [19] [20].

Histograms of homogenization temperatures and salinities (Figure 5) and diagram of homogenization temperatures versus salinities (Figure 7) indicate a wide range of homogenization temperatures from $140^{\circ} \mathrm{C}$ to $395^{\circ} \mathrm{C}$, and medium-low salinities from $0.53 \%$ to $22.01 \%$, respectively. Type I inclusions, along with minor type II and type III inclusions are present in stage A. Homogenization temperatures for type I inclusions range from $180^{\circ} \mathrm{C}$ to $300^{\circ} \mathrm{C}$, whereas that of type II inclusions are from $268^{\circ} \mathrm{C}$ to $366^{\circ} \mathrm{C}$, with calculated salinities from $0.53 \%$ to $21.44 \%$. In addition to development of type I inclusions, type II and III inclusions increased significantly in stage B. Homogenization temperatures of type I inclusions range from $160^{\circ} \mathrm{C}$ to $250^{\circ} \mathrm{C}$, and that of type II inclusions are of $260^{\circ} \mathrm{C}-360^{\circ} \mathrm{C}$, with calculated salinities from $1.32 \%$ to $22.01 \%$. Based on microthermometric results, no obvious decrease of salinities is observed along with a decrease in temperature from stage A to stage B, showing a natural cooling process of the system, indicating that the mineralization occurred during the internal fluid evolution, however, the large range of salinity indicates a wide source of fluid, maybe mixed with low-salinity exotic fluid. 


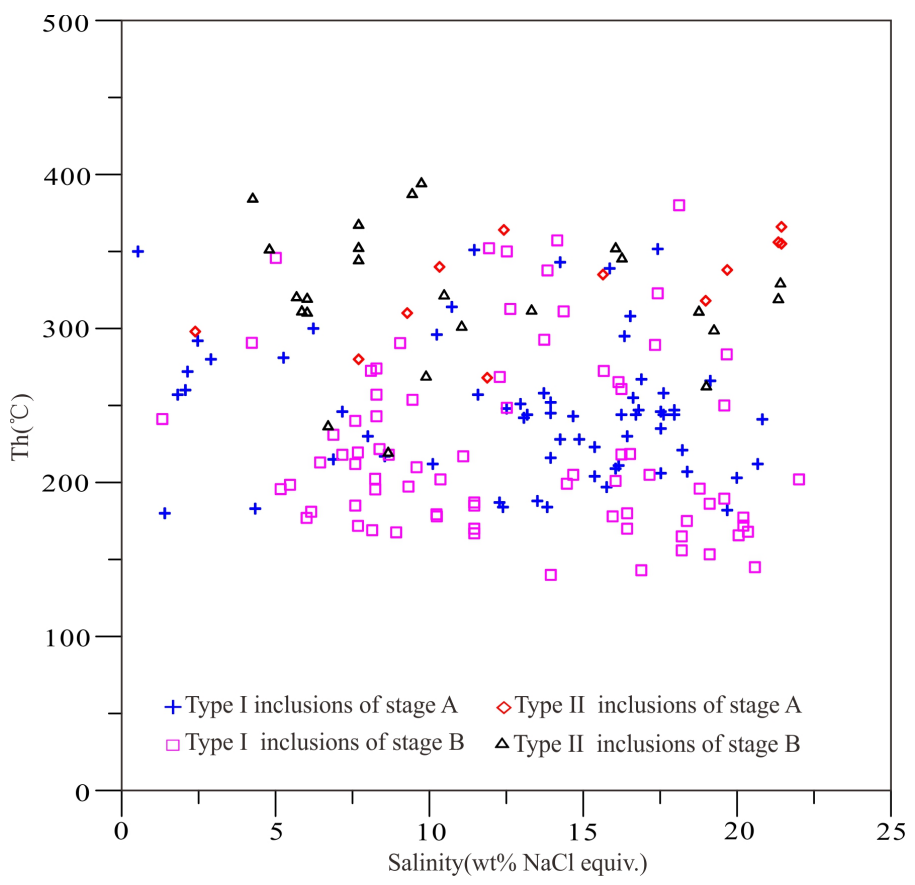

Figure 7. Correlation between homogenization temperatures and salinities of inclusions in Annage deposit.

On the $\delta \mathrm{D}-\delta^{18} \mathrm{OH}_{2} \mathrm{O}$ diagram (Figure 6), samples of main mineralization stage in Guoluolongwa deposit mostly plot in magmatic/metamorphic water area, reflecting that ore-forming fluid in the area mainly derived from magmatic/metamorphic water [3]; whereas most samples of Annage plot between left side of magmatic water box and metamorphic water line, and one is located in magmatic water area, indicating a primary magmatic origin for the mineralizing process and mixed with other fluids (maybe metamorphic hydrothermal). High density of $\mathrm{SO}_{4}{ }^{2-}$, representing all phases of sulfur, including $\mathrm{S}^{2-}, \mathrm{HS}^{-}, \mathrm{SO}_{4}{ }^{2-}$ and etc [21], has effectively indicates the existence of magmatic water in ore-forming fluids. Abundance of $\mathrm{SO}_{4}{ }^{2-}$ in ore-forming fluids of main mineralization stage speculated the presence of magmatic hydrothermal, corresponding to the fact that one projection point is situated at the magmatic water area on the hydrogen-oxygen isotope diagram.

Based on diagram of homogenization temperatures versus salinities (Figure 7), homogenization temperatures of most type I inclusions are from $140^{\circ} \mathrm{C}$ to $300^{\circ} \mathrm{C}$, which may reflect the ore-forming temperature, whereas that of type II inclusions and some type I inclusions are slightly higher, showing characteristics of heterogeneous capture, and are of no significance. Salinities of fluid inclusions are mostly medium-low values, clustering around $7 \%$ - 22\%. However, occurrence of low salinity inclusions, namely $0.53 \%$, reflects the addition of low salinity fluid during mineralization process. Besides, a continuous decrease in temperature may indicate a natural cooling process of the fluid, inferring that the mixed water maybe high-temperature, low-salinity water (probably metamorphic hydrothermal) derived from the deep, or underground water.

To sum up, ore-forming fluids in Annage gold deposit are of $\mathrm{CO}_{2}$-rich, $\mathrm{H}_{2} \mathrm{O}-\mathrm{NaCl}-\mathrm{CO}_{2}$ type with mediumhigh temperatures $\left(140^{\circ} \mathrm{C}->300^{\circ} \mathrm{C}\right)$ and medium-low salinities $(0.53 \%-22.01 \%)$ and experienced immiscibility during the mineralization process [22]. The original $\mathrm{H}_{2} \mathrm{O}-\mathrm{NaCl}-\mathrm{CO}_{2}$ fluid with medium-high temperature and medium salinity separated into $\mathrm{NaCl}-\mathrm{H}_{2} \mathrm{O}$-rich (with few $\mathrm{CO}_{2}$ ) fluid and $\mathrm{CO}_{2}$-rich, medium-low salinity fluid, and mixed with high-temperature metamorphic hydrothermal or groundwater in the late.

\subsection{Pressure Conditions of Mineralization}

Inclusion trapping pressure could be obtained from the homogeneous temperature of pure $\mathrm{CO}_{2}$ and pure water inclusions at the P-T diagram of $\mathrm{H}_{2} \mathrm{O}$ and $\mathrm{CO}_{2}$ combined systems if pure $\mathrm{CO}_{2}$ inclusions and pure water inclusions were simultaneously trapped. In this study, the two end compositions trapped by the inclusions in stage $\mathrm{B}$ were used to estimate pressure by the isometric intersection method. The trapping pressures of inclusions obtained from the isometric intersection in the two ends are shown in Figure 8, with the pressure ranging from 79 


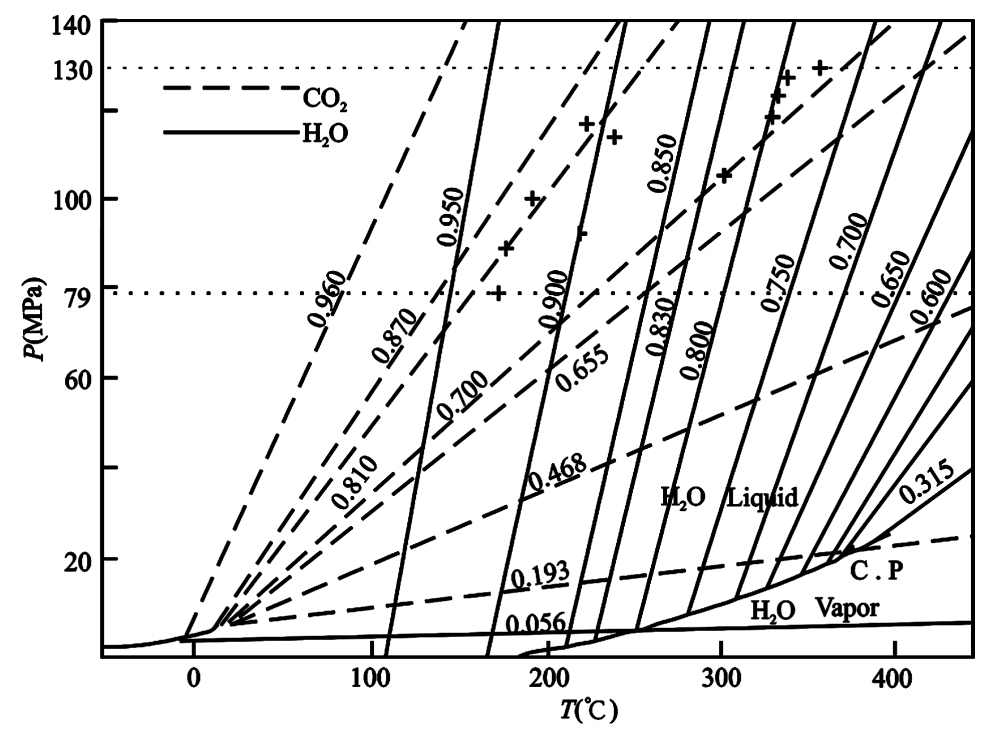

Figure 8. P-T diagrams of H2O-CO2 system (Modified from Roedder and Bodnar [7]).

MPa to $130 \mathrm{MPa}$, corresponding to trapped temperatures from $185^{\circ} \mathrm{C}$ to $350^{\circ} \mathrm{C}$. Sulfides are formed later than quartz, with slightly lower temperatures than that of quartz. Therefore, the range of $185^{\circ} \mathrm{C}-350^{\circ} \mathrm{C}$ represents the upper limit of mineralization temperature, indicating that ore-forming temperature is of medium-high type.

Based on the estimated pressure, we calculated the mineralization depth. Considering that the study area is in compressive orogenic environment, metallogenic depth can be estimated via lithostatic pressure using the formula: $\mathrm{H}=\mathrm{P} /(\rho \times \mathrm{g})\left(\rho\right.$ represents average density of rocks, namely $\left.2.70 \mathrm{~g} / \mathrm{cm}^{3}\right)$. The maximum pressure of 130 MPa corresponds to an upper limit depth of $4.8 \mathrm{~km}$.

\subsection{Ore-Forming Fluid Evolution}

Ore-forming fluids in the deposit area are characterized by wide range of homogenization temperatures and salinities as well as high density of $\mathrm{CO}_{2}$ and $\mathrm{CH}_{4}$. Wall rock alterations are dominated by silicification, sericitization and carbonation, indicating that ore-bearing hydrothermal is rich in $\mathrm{Si}, \mathrm{CO}_{2}$ and alkali. $\mathrm{CO}_{2}$ in the fluids may be mainly from mantle, medium-high grade metamorphic fluid from lower crust and magmatic fluid, whereas $\mathrm{CH}_{4}$ may be derived from deep-source fluids and organic-rich sedimentary metamorphism. On basis of micro-thermometry, ore-forming fluids are mainly deep-source magmatic hydrothermal fluid at the early stage [23], and then mix with low-salinity metamorphic hydrothermal or underground water in the late. Evolution of fluids experienced multistages.

At the early mineralization stage, ore-forming fluids are $\mathrm{CO}_{2}$-rich magmatic hydrothermal which may be derived from high salinity intermediate-acid magmatic hydrothermal, and form high-salinity high-temperature fluid inclusions.

At the main mineralization stage, natural cooling occurs in the ore-forming fluids. Upward intrusion of fluids to the shallow crust along EW fracture zone brings about the mineralization pressure transition from lithostatic to hydrostatic, causing repeated fluid immiscibility. Fluid immiscibility has been reported as one of the most important mechanisms for mineralization in many hydrothermal deposits [6] [24], and the $\mathrm{H}_{2} \mathrm{O}-\mathrm{NaCl}-\mathrm{CO}_{2}$ fluid immiscibility is closely related to gold mineralization [25]. $\mathrm{H}_{2} \mathrm{O}-\mathrm{NaCl}-\mathrm{CO}_{2}$ fluid immiscibility can cause phase separation, resulting in the escape of volatiles, such as $\mathrm{CO}_{2}, \mathrm{CH}_{4}$ and $\mathrm{N}_{2}$. The original $\mathrm{NaCl}-\mathrm{H}_{2} \mathrm{O}-\mathrm{CO}_{2}$ fluids of Annage deposit separated into $\mathrm{CO}_{2}$-rich fluids and $\mathrm{H}_{2} \mathrm{O}$-rich fluids, resulting in capture of low-salinity $\mathrm{CO}_{2}$-bearing inclusions and slightly higher-salinity aqueous inclusions. During phase separation, escape of $\mathrm{CO}_{2}$ and $\mathrm{CH}_{4}$, concentration of ore-forming fluid and decomposition of carbonate ion and bicarbonate ion lead to huge changes in fluid composition and physical and chemical conditions, leading to decrease of Au solubility in ore-forming fluids and the rapid precipitation of gold in the favorable ore-hosting structures.

At the late mineralization stage, a sudden reduction of $\mathrm{CO}_{2}$-bearing inclusions occurs due to escape of $\mathrm{CO}_{2}$. Ore-forming fluid system transits from a relatively closed state to an open state, which is beneficial to addition 
of other fluids. Based on the above discussion, deep-source low-salinity high-temperature metamorphic hydrothermal or underground water are speculated to mix with magmatic fluid, resulting in decrease of fluid salinities and capture of low-salinity inclusions..

\subsection{Ore Genesis}

Annage gold deposit is located at east section of eastern Kunlun belt. The eastern Kunlun orogenic belt experienced multicycle evolution, and the late Variscan-Indosinian tectonic cycle is the most closely related to gold mineralization [26]. Intensive tectonic and magmatic activities occurred in the late Variscan-Indosinian period, formed a series of deep faults, shear zone and fracture-fissure structures, as well as large-scale magmatite intrusion, and provided metallogenic dynamics and mineral sources. The metallogenic mechanism is as follows.

In Caledonian period, intracontinental subduction took place in eastern Kunlun belt, led to the ore-forming fluid activation and initial enrichment of ore-forming materials. Few intermediate-acidic magmatite of this period was developed in Annage deposit.

In Variscan-Indosinian period, strong subduction and collision, intensive tectonic deformation and metamorphism occurred, forming the EW shear zone. The dynamic metamorphism is obviously observed along the fracture zone. Besides, subduction and collision provides thermal and power for migration of $\mathrm{CO}_{2}$-rich magmatic hydrothermal along the EW shear zone. During the migration, water-rock interaction between wall rock and hydrothermal fluid contributes to further enrichment of minerals, forming ore-bearing hydrothermal solution with higher temperature.

In Indosinian-Yanshanian period, secondary tensional faults and shear fractures are formed on both sides of the nearly EW shear zone, and ultramafic rocks are developed near the shear zone. Fluids rich in ore minerals moved upward along the shallow tensional fault system. Addition of shallow underground water destroyed balance of ore-bearing hydrothermal, resulted in fluid immiscibility and escape of large amounts of $\mathrm{CO}_{2}, \mathrm{CH}_{4}$, thus forming the residual fluids containing large amounts of $\mathrm{Au}, \mathrm{Ag}$ and other minerals. Decrease of pressure and fluid temperature, addition of extraneous fluid reduced the solubility of ore-forming minerals in the fluid, bringing about precipitation of minerals in the EW shear zone and the SN tensional fault. Furthermore, metasomatism between metallogenic hydrothermal and fracture zone or wall rocks formed quartz-vein and altered rocks, and then finally formed gold ore bodies.

To sum up, Annage gold deposit is a medium-high temperature magmatic hydrothermal quartz vein type deposit formed in intracontinental orogenic environment.

\section{Conclusions}

Two types of ore bodies, namely quartz vein type and altered rock type are produced in EW and NS faults. Mineralization in the deposit area is classified into three stages: quartz-pyrite stage (A), quartz-polymetallic-sulfide stage (B) and quartz-ankerite stage (C).

Three types of fluid inclusions, aqueous inclusions (type I), $\mathrm{CO}_{2}$-bearing inclusions (type II) and pure $\mathrm{CO}_{2}$ inclusions (type III) are well developed in stages A and B, having homogenization temperatures range from $140^{\circ} \mathrm{C}$ to $395^{\circ} \mathrm{C}$, and salinities from $0.53 \%$ to $22.01 \%$. Based on hydrogen-oxygen isotope analysis, values of $\delta^{18} \mathrm{O}_{\mathrm{V} \text {-SMow }}$ and $\delta^{18} \mathrm{D}$ range from $10.6 \times 10^{-3}$ to $12.9 \times 10^{-3}$ and $-83.8 \times 10^{-3}$ to $-72.3 \times 10^{-3}$. Ore-forming fluids of Annage gold deposit are dominated by magmatic hydrothermal at the early, and mix with metamorphic hydrothermal or underground water in the late.

Formation of Annage gold deposit is closely related to late Variscan-Indosinian orogenic movement, and ore-forming fluids of the deposit are deep-source magmatic fluids rich in $\mathrm{Si}, \mathrm{CO}_{2}$ and alkali. With the power of subduction and collision, ore-bearing fluids moved upward along the deep fault, extracted ore minerals, and caused a decrease of pressure. Addition of underground water or metamorphic thermal in the late led to fluid immiscibility and escape of large amounts of $\mathrm{CO}_{2}, \mathrm{CH}_{4}$ and etc., resulting in precipitation of metallogenic minerals in the favorable ore-hosting space. The Annage gold deposit, with estimated metallogenic pressures of 79 $130 \mathrm{MPa}$, which corresponds to a calculated upper limit depth of $4.8 \mathrm{~km}$, belongs to magmatic hydrothermal quartz vein type.

\section{Acknowledgements}

This study is supported by the China Geological Survey Investigation Programs (No.2006BAA01B06) and in- 
novation-driven project of Central South University. Petrographic and microthermometric studies were carried out at the Geofluids Laboratory in Central South University. Hydrogen-oxygen isotope analysis was carried out in Beijing Research Institute of Uranium Geology. Special thanks are due to the management and staff of Annage Mine and No. 8 Team, Qinghai Bureau of Nonferrous Metals Geological Exploration for their hospitality and valuable help during fieldwork. Jinjin Tao, Feng Zhou, Baorong Yang and Xiaoyun Wang are thanked for their contribution and constructive review, which improved the quality of the paper.

\section{References}

[1] Hu, R.G., Lai, J.Q., Zhang, S.N., Dou H.W., Shi, G.H. and Yang, B.R. (2010) Geological and Geochemical Characteristics of the Guoluolongwa Gold Deposit, Dulan County, Qinghai Province. Geology and Exploration, 46, 931-941.

[2] Zou, D.X., Yang, X.B. and Lu, W.Q. (2011) Isotope Characteristics and Ore Genesis of Guoluolongwa Gold Deposit in Qinghai Province. Gold Science and Technology, 19, 26-30.

[3] Ding, Q.F., Jin, S.K., Wang, G. and Zhang, B.L. (2013) Ore-Forming Fluid of the Guoluolongwa Gold Deposit in Dulan County, Qinghai Province. Journal of Jilin University (Earth Science Edition), 43, 415-425.

[4] Qi, Y.Q. and He, J.J. (2012) Geochemical Characteristics of Gouli Gold Deposit in Dulan County, Qinghai Province. Exploration Engineering, 7, 142-147.

[5] Li, B.L., Shen, X., Chen, G.J., Yang, Y.Q. and Li, Y.S. (2012) Geochemical Features of Ore-Forming Fluids and Metallogenesis of Vein I in Asiha Gold Ore Deposit, Eastern Kunlun, Qinghai Province. Journal of Jilin University (Earth Science), 42, 1676-1687.

[6] Roedder, E. (1984) Fluid Inclusions. In: Ribbe, H.P., Ed., Reviews in Mineralogy, Mineralogical Society of America, Washington DC, 12, 1-644.

[7] Roedder, E. and Bodnar, R.J. (1980) Geologic Pressure Determinations from Fluid Inclusion Studies. Annual Review of Earth and Planetary Sciences, 8, 263-301. http://dx.doi.org/10.1146/annurev.ea.08.050180.001403

[8] Xu, Z.Q., Yang, J.S., Li, H.Q., Wang, R.R. and Cai, Z.H. (2012) Indosinian Collision-Orogenic System of Chinese Continent and Its Orogenic Mechanism. Acta Petrologica Sinica, 28, 1697-1709.

[9] Jiang, C.F., Yang, J.S. and Feng, B.G. (1992) Opening-Closing Tectonics of Kunlun. Geological Publishing House, Beijing, 1-224.

[10] Chen, G.C., Pei, X.Z., Li, R.B., Li, Z.C., Pei, L., Liu, Z.Q., Chen, Y.X., Liu, C.J., Gao, J.M. and Wei, F.H. (2013) Geochronology and Genesis of the Helegang Xilikete Granitic Plutons from the Southern Margin of the Eastern East Kunlun Orogenic Belt and Their Tectonic Significance. Acta Geologica Sinica, 87, 1525-1541.

[11] No. 8 Team, Qinghai Bureau of Nonferrous Metals Geological Exploration and Central South University. (2013) Prospecting Integrated Exploration Deployment Report of Gold Polymetallic Area in Gouli, Qinghai Province (Internal Information).

[12] Kui, M.J., Bai, H.X., Gu, F.B. and Miao, G.W. (2010) Division of East Kunlun Tectonic Magmatic Belt and the Rock Tectonic Combination in the Late Variscan-Yanshanian Period. Journal of Qinghai University (Nature Science), 28, 49-55.

[13] Brown, P.E. and Lamb, W.M. (1989) P-V-T Properties of Fluids in the System $\mathrm{CO}_{2}-\mathrm{H}_{2} \mathrm{O}-\mathrm{NaCl}$ : New Graphical Presentations and Implication for Fluid Inclusions Studies. Geochimica et Cosmochimica Acta, 53, 1209-1221. http://dx.doi.org/10.1016/0016-7037(89)90057-4

[14] Brown, P.E. (1989) FLINCOR: A Microcomputer Program for the Reduction and Investigation of Fluid Inclusion Data. American Mineralogist, 74, 1390-1393.

[15] Clayton, R.N. and Mayeda, T.K. (1963) The Use of Bromine Pentafluoride in the Extraction of Oxygen from Oxides and Silicates for Isotopic Analysis. Geochimica et Cosmochimica Acta, 27, 43-52. http://dx.doi.org/10.1016/0016-7037(63)90071-1

[16] Friedman, I. (1953) Deuterium Content of Natural Waters and Other Substances. Geochimica et Cosmochimica Acta, 4, 89-103. http://dx.doi.org/10.1016/0016-7037(53)90066-0

[17] Diamond, L.W. (2001) Review of the Systematics of $\mathrm{CO}_{2}-\mathrm{H}_{2} \mathrm{O}$ Fluid Inclusions. Lithos, 55, 69-99. http://dx.doi.org/10.1016/s0024-4937(00)00039-6

[18] Sheppard, S.M.F. (1986) Characterization and Isotopic Variations in Natural Water. Reviews in Mineralogy, 16, 165-183.

[19] Clayton, R.N., O’Neil, J.R. and Mayeda, T.K. (1972) Oxygen Isotope Exchange between Quartz and Water. Journal of Geophysical Research, 77, 3057-3067. http://dx.doi.org/10.1029/jb077i017p03057

[20] Lu, H.Z. (2011) Fluids Immiscibility and Fluid Inclusions. Acta Petrologica Sinica, 27, 1253-1261. 
[21] Chen, Y.J., Li, J., Pirajno, F., Lin, Z.J. and Wang, H.H. (2004) Hydrothermal Metallogeny of the Shanggong Gold Deposit, East Qinling: Studies on Ore Geology and Fluid Inclusion Geochemistry. Journal of Mineralogy and Petrology, 24, 1-12.

[22] Mernagh, T.P., Bastrakov, E.N., Zaw, K., Wygralak, A.S. and Wyborn, L.A.I. (2007) Comparison of Fluid Inclusion Data and Mineralization Processes for Australian Orogenic Gold and Intrusion-Related Gold Systems. Acta Petrologica Sinica, 23, 21-32.

[23] Gao, Y.B., Li, W.Y. and Zhang, Z.W. (2011) Fluid Inclusions and H-O Isotope Compositions of Quartz-Vein Ores in the Baiganhu-Jialesai W-Sn Mineralization Belts, Qimantage, NW China. Acta Petrologica Sinica, 27, 1829-1839.

[24] Klemm, L.M., Pettke, T. and Heinrich C.A. (2008) Fluid and Source Magma Evolution of the Questa Porphyry Mo Deposit, New Mexico, USA. Mineralium Deposita, 43, 533-552. http://dx.doi.org/10.1007/s00126-008-0181-7

[25] Craw, D. (1992) Fluid Evolution, Fluid Immiscibility and Gold Deposition during Cretaceous-Recent Tectonics and Uplift of the Otago and Alpine Schist, New Zealand. Chemical Geology, 98, 221-236. http://dx.doi.org/10.1016/0009-2541(92)90186-9

[26] Feng, C.Y., Zhang, D.Q., Wang, F.C., Li, D.X. and She, H.Q. (2004) Geochemical Characteristics of Ore-Forming Fluids from the Orogenic Au (and Sb) Deposits in the Eastern Kunlun Area, Qinghai Province. Acta Petrologica Sinica, 20, 949-960. 